\title{
Identification of the Type of Strategic Policy for Sustainable Development on the Basis of Territorial Characterization. A Case Study in Canton Baños de Agua Santa, Tungurahua, Ecuador
}

\author{
Jose Fabian Fonseca Vasconez ${ }^{1}$, Andrea del Pilar Ramirez Cascoㄹ, \\ Mario Alfonso Arellano Diaz ${ }^{1}$, Xavier Sulca Guale ${ }^{2}$ \\ ${ }^{1}$ Escuela Superior Politécnica del Chimborazo, Riobamba, Ecuador \\ ${ }^{2}$ Universidad Técnica de Ambato, Ambato, Ecuador \\ Email: economi79@hotmail.com, andrea.ramirez@espoch.edu.ec, arellanodaz@hotmail.com,manuelxsulcag@uta.edu.ec
}

How to cite this paper: Fonseca, J.F., Ramirez, A., Arellano, M.A. and Sulca, X. (2017) Identification of the Type of Strategic Policy for Sustainable Development on the Basis of Territorial Characterization. A Case Study in Canton Baños de Agua Santa, Tungurahua, Ecuador. Theoretical Economics Letters, 7, 1545-1556. https://doi.org/10.4236/tel.2017.75104

Received: July 20, 2017

Accepted: August 21, 2017

Published: August 24, 2017

Copyright $\odot 2017$ by authors and Scientific Research Publishing Inc. This work is licensed under the Creative Commons Attribution International License (CC BY 4.0).

http://creativecommons.org/licenses/by/4.0/

\section{(c) (i) Open Access}

\begin{abstract}
This study was carried out in Baños de Agua Santa, Province of Tungurahua-Ecuador; From the time of Spanish colonization to the present day, the failure to implement sustainable development policies has led to the decline of some economic activities and has driven tourism as the main source of income without structured sustainable guidelines with established planning for which becomes a fundamental alternative axis, generating the depletion of tourism resources and territorial disorder, the product of an imposing mercantilist system that guides competitiveness in an indiscriminate way. In correspondence the objective was to identify the type of strategic policy for the sustained development of the tourist destination referred to. Methodologically the study uses theoretical methods such as analysis and synthesis, inductive-deductive, historical-logical, others of the empirical level, among which we can cite the criterion of experts, matrices of analysis such as: external factor evaluation (EFE), evaluation of Internal factors (EFI), SWOT analysis, strategic evaluation and position of action (PEEA) and descriptive statistics. The results obtained were the determination of the present and future incidence of economic activities in the territory under study and the projection of the type of strategic policy for sustainable and responsible management of natural, cultural, socio-productive resources, preventing different Economic cycles, through the evaluation of their productive factors.
\end{abstract}

\section{Keywords}

Processes Management, Sustainability, Territorial Ordering,

Tourist Destination 


\section{Introduction}

Territorial management is the planned systematization that promotes sustainable use of the territory through the integration of resources-human, financial, organizational, political and natural, as well as territorial. They seek to meet the individual and collective needs of different sectors of the population. Public administration is responsible for managing the territory to eliminate economic imbalances, and to promote dynamic systematized between urban and rural areas, whose social cohesion is a generator of development [1] [2] [3].

In the year 2013, the German Social Cooperation and Technical Assistance, in its report on territorial management, argues that the territorial management points to a sustainable development because it harmonizes the proposals for development of the population with the potentials and resources of the territory.

For this reason, it is considered that territorial management allows resources to be used in a reasonable way, generating sustainability over time and ensuring that these resources are perpetuated with a vision to meet present and future needs of the people through the optimization of the potentials and resources of the territory. Territorial management is made up of diagnosis and self-test, spatial planning, strategic plan of institutional development and policy development because territorial management should answer the following questions: Why do we want to do territorial management?, Who do we do territorial management with?, What is our wealth?, What are our strengths and values?, What do we want?, How do we do it?; and How it has been demonstrated in the investigations carried out by Alen, Calvo, Hernán, Massiris [4] [5] [6] [7].

Territorial management assumes a wide range of units of analysis which focuses on the selection of interests and objectives to investigate, diagnose and pedrict, Rodriguez (2010). The analysis of the territorial management focuses on the analysis of variables such as: natural physical units, the political-administrative division, environmental units, sensitive ecosystems, landscape units anthropized rural and urban areas, port areas, and tourist poles [8].

This work agrees with Delgadillo (2009), he stated that the development of a region depends on its ability to stimulate local initiatives, generate new businesses and lead a dynamic of territorial innovation. This is a definition that is consistent with the development in Ecuador which has evolved around the evolution of its population and needs [9].

The Constitution of the Republic of Ecuador (2008), sets four provisions related to State policy, on the basis of that legal framework, the National Secretary of Planning and Development (SENPLADES), leads the process of the Plan Nacional del Buen Vivir "National Plan for Well-being" 2013-2017. This plan considers the territory as a multidimensional and dynamic social construction that allows the national public policy to articulate with the specific conditions and characteristics of the territory (continental, marine and island) where the territorial planning guidelines are directed toward the search for a territorial rebalancing by reducing the imbalances in social, economic, environmental and infrastructure, to achieve well-being. This plan has been called the National Terri- 
torial Strategy [10] [11].

The National Plan of Well-being, is the first planning tool that articulates sub-national levels (provincial, cantonal and parish). Also, according with the provisions of articles 10 and 53 of the Organic Code of Planning and Finance (COPFP), it establishes the National Territorial Strategy (TNCS). This plan constitutes a complementary instrument to the National Plan for Well-being that allows to articulate the national public policy to the specific conditions and characteristics of the territory.

The Strategic Plan for the Development of Sustainable Tourism in Ecuador PLANDETUR 2020, promotes a process to coordinate the efforts of public, private and community for the development of sustainable tourism based on territories and under the principles of poverty alleviation, equity, sustainability, competitiveness and decentralised management by taking advantage of the comparative advantages and uniqueness of the country [12].

Currently, the report of the Ministry of Finance of the Republic of Ecuador believes that tourism represents $5.93 \%$ of the national GDP, which shows how the standard planning process drives this economic activity. In Ecuador, there are various tourist places; Baños de Agua Santa is one of those places. Baños is the territory object of this study and it is the third most visited tourist destination along the country.

However, mercantilism is impregnated in the mentality of the providers of tourist services of Baños de Agua Santa. It promotes a media atmosphere that constantly destroys weak development programs that posses a short-term, populist, inefficient operational planning whose dynamics of change are never at the pace of new trends in a globalized world. This is a product of the application of non-validated processes in scientific theories.

In such circumstance to transform it into a positive state, it is necessary to control the territorial operation on the basis of sustainable management processes which aims to identify the type of strategic policy for the sustained development of the tourist destination. Its methodology is based on the use of theoretical methods such as; analysis and synthesis, inductive-deductive, logical-historical, among others from the empirical level such as; the criteria of experts, analysis matrix like, external factors evaluation (EFE), internal factors evaluation (EFI), SWOT analysis, evaluation and strategic position of action (EEAP) and descriptive statistics.

It is assumed that the growth of the tourist activity in a territory promotes the need to develop and apply knowledge based on valid disciplines that help to prevent these economic sectors that revolve around a specific activity. Therefore, they enter into a process of economic recession which allow us to understand the importance of sustainability as an emerging and cross-cutting phenomenon that requires special attention, and the systematic coordination of the private and public sector.

For this reason, it is imperative to understand that to adopt a development approach to the protection of the environment as an alternative to the models 
that have led to the degradation of the environment, it is necessary to promote productive and social processes during generational lapses until reaching a situation of sustainable development in accordance to what was established with the Brundtland Report (1987); and ratified at the Earth Summit (1972), formulated by the World Commission on Environment and Development of the United Nations, known as the "Rio Declaration", or Agenda 21.

Authors such as Mesino (2011); Aguilar (2015); Adams (2015); considered to sustainable development as the substantive improvement of the levels and quality of life; context that promotes interaction between three areas: ecological, economic and social development and between three models of development: viable, sustainable and equitable [13] [14] [15].

However, it coincides with Taddei, (2011), who changes the classic vision of the concept of Sustainable Development. This vision considers only three areas; ecological, economic and social development, plus the institutional level for the analysis of territorial realities complicated from the physical and social world, which is part of the normative and legal factors [16].

Finally, it is established that the identification of the type of strategic policy for sustainable development, starting from the analysis of the processes of territorial management and the characterization, rather than a point of arrival, is a starting point, which marks the break between a development model that commercialize the State-Society-Nature relations. There is a new policy which exceeds the reductionist vision of development as economic growth toward an approach that focuses on the human being, through the approach of strategies validated in critical analysis.

\section{Methodology}

The methodology applied is based on research conducted by various authors that have deepened into the subject area, such as: Serna (1999), the National Institute of Statistics and Censuses [17] [18] [19] [20]. This analysis started with the identification of the problem, which results helped identifying the type of strategic policy for sustainable development, on the basis of theoretical research methods such as; analysis and synthesis, inductive-deductive, logical-historical, and others from the empirical level like the criteria of experts evaluated in the abacus of Regnier and strategic planning tools such as: Analysis SWOT, EFI, EFE, EEAP and descriptive statistics, weighting with point scoring.

Figure 1 is the conductor of the proposal.

The analysis of the processes of territorial management and the characterization allows us to have a baseline based on past and current facts, which can be quantified through the theoretical foundations of strategic planning, and applied in a given territory, promoting the improvement of territorial management processes [21] [22].

\section{Results}

Baños de Agua Santa, named after many spas that exist in town was legally con- 


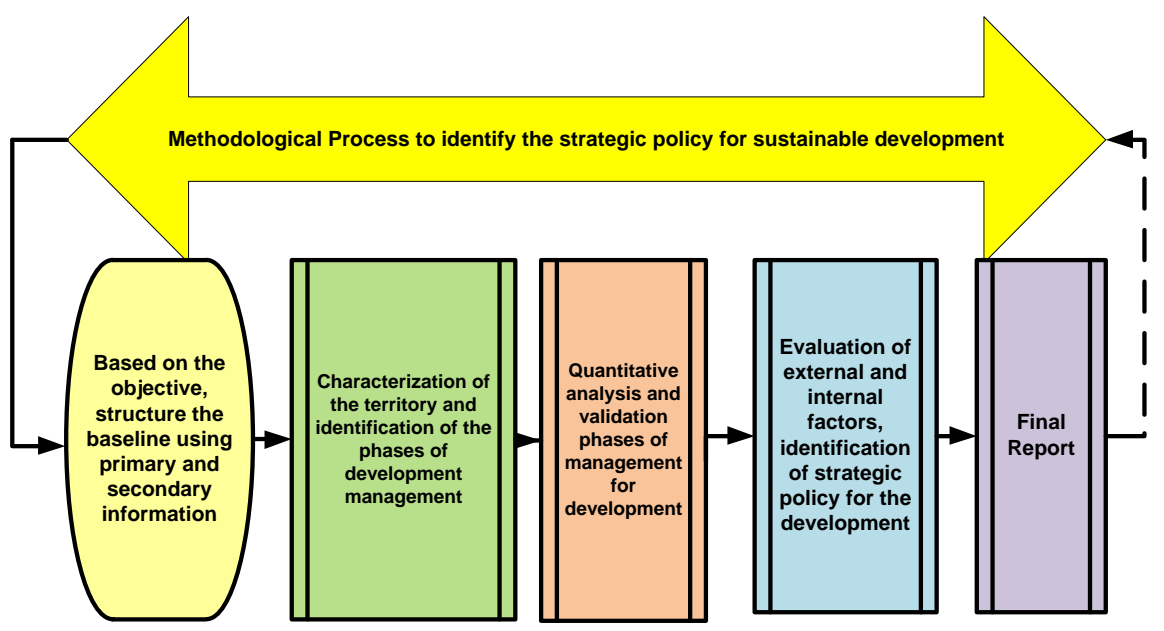

Figure 1. Conductor of the proposal. Source: Authors.

stituted as a canton in 1944 according to official registration of 2 December 1944.

It is located in the province of Tungurahua, Ecuador-South America, in the Eastern mountain range to $185.8 \mathrm{~km}$ south east of the capital Quito, between the $01^{\circ} 12^{\prime} 09^{\prime \prime}$ and $01^{\circ} 38^{\prime} 05^{\prime \prime}$ South latitude and between $78^{\circ} 06^{\prime} 05^{\prime \prime}$ and $78^{\circ} 28^{\prime} 34^{\prime \prime}$ west longitude, and it is 1800 meters above sea level. It has an area of approximately $1073 \mathrm{~km}^{2}$, equivalent to 107,300 hectares. The total population of Baños is 20,018 inhabitants. The population density is 19 inhabitants $/ \mathrm{km}^{2}$.

Its political and administrative division is made up of four rural parishes, Rio Verde (1308 inhabitants), Rio Negro (1244 inhabitants), Lligua (280 inhabitants), Ulba (2533 inhabitants), and the city of Baños (14,653 inhabitants). Baños is characterized by a high percentage of young population, the $69 \%$ is less than 40 years, $11 \%$ between 40 and 50 years and $20 \%$ of 50 onwards.

It is bordered to the north by Tena (province of Napo), to the south by Penipe (province of Chimborazo) and Palora (province of Morona Santiago), to the east Mera (province of Pastaza) and Patate to the West.

Baños de Agua Santa has an area rich in biodiversity, close to 22 per cent of the zone territory is under the National System of Protected Areas (ecological corridor Llanganates-Sangay). There are 184 endemic plant species; 91 are orchids, 270 species of birds, 101 species of mammals which 21 of them have some degree of extinction threat. Its strategic geographical location between the Ecuadorian highlands and the Amazon makes it suitable for the development of tourist, agricultural, environmental, energy, crafts and service activities. Therefore, they can become an important center at the national and international levels.

Baños de Agua Santa is renowned for being the gateway to the Ecuadorian Amazon Region. It is listed as one of the first tourist destinations of Ecuador. Tourists can find approximately 101 various attractive places for recreation, adventure, entertainment and religious activities. Locals and foreigners always highlight every place they visit because they can find attractions like, the local 
gastronomy, crafts, thermal springs, extreme sports, a zoo called "San Martín", the path of the Waterfalls, Pailon del Diablo, Sangay and Llanganates National Parks, Tungurahua volcano ( in process of eruption) and the ecological corridor known as a gift to the earth, which is recognized by its great biodiversity in the World, thus all these attractions promote the importance of tourism as the main economic activity in the region.

The geographical characteristics of the region have led to the Economically Active Population (EAP) 9291 people. These people develop a number of activities including agriculture 28\%, manufacturing 7.89\%, commerce $16.11 \%$, and tourism as it primary economic activity. Baños de Agua Santa is one of the most important tourist centers of Ecuador with tourist infrastructure of any category. It is a tourist destination surrounded by several rivers, waterfalls, hot springs that are rich in minerals that emerge from the bowels and thaws of the Tungurahua volcano. All these features allow visitors to carry out extreme sports such as; White water-rafting, climbing, canyoning, trekking or swing jump.

Baños has an important and recognized religious tourism. Visitors can go to the Church Del Rosario de Agua Santa Virgin. Devotees come and visit this tourist spot on a regular basis, specially on the Holy Week. A pilgrimage called The Faith Trek attracts people from different parts of Ecuador creating a tourist influx of approximately 6000 people.

On this basis of tourists that visit the place, it is established that $86 \%$ of visitors are Ecuadorians; $67 \%$ of them have higher academic degrees, 33 per cent of the tourists come to this place because they have been to this place before and they know it now. $63 \%$ of them got information from the Internet and the $57 \%$ return to this place more than three times. $45 \%$ of the tourists do not use the services of any of the 58 travel agencies in town. Tourists stay is at least 1 day (43\%). The most widely used means of transport is the public (57\%). The majority of tourists are males (67\%), and $36 \%$ of visitors are among ages 20 to 29 years.

Among all the tourist attractions that Baños offers, it can be mentioned the most important by different categories:

- Cultural: Cathedral of Del Rosario de Agua Santa Virgin, City Museum, Ecological Garden Brindabana.

- Natural Sites: The Tungurahua volcano, hot springs, waterfalls such as: Cabellera de la Virgen, Chamana, Río Ulba, La Piedra la Luz, Manto de la Novia, San Jorge, San Pedro, Pailon del Diablo, Machay, Manto del Angel, Las Orquídeas, San Agustín, Refugio de los Loros, San Miguel, Peñon del Tucán, Manantial del Dorado, Cashuarco.

- Canyons: San Martin, El duende.

- Rivers and riversides: Río Verde, Río Las Estancias, Río Zúñiga. Lligua volcanic viewpoint.

- Contemporary artistic or technical spots: Serpentarium, Eco Zoo San Martin.

- According to the Decentralized Autonomous Government of Baños, the tourist offer of the city is based on five key activities: Hotels and Accommo- 
dation, Recreational Facilities, Travel Agencies, and Food and Crafts.

According to research by: Reyes (2001); Vieira (1991), Sanchez (1979); and the studies for the structuring of the Local Development Plans and Territorial (1995); (1997); (2002); (2010); Baños de Agua Santa has gone through several phases of management for territorial development [23]-[29]. As shown below (Table 1).

The evaluation of various management processes such as; the Abacus of Regnier and Kendall's coefficient of concordance or coefficient of Rank Correlation $(\mathrm{W})$, and the selection of experts using the coefficient $\mathrm{K}$ of the competence of the expert $\mathrm{K}=1 / 2(\mathrm{Kc} \mathrm{Ka})$, presents the following results (Table 2).

Table 1. Matrix of parameters of development of Baños.

\begin{tabular}{|c|c|}
\hline Parameter & General characterization of the parameter \\
\hline $\begin{array}{l}\text { Development prospects } \\
\text { (Colonial era-1553) }\end{array}$ & $\begin{array}{l}\text { Report that identifies three areas of development such as: } \\
\text { trade, industry, tourism and does not consider agriculture } \\
\text { despite being the main economic activity at that time. }\end{array}$ \\
\hline $\begin{array}{l}\text { Local development } \\
\text { proposal-1944 }\end{array}$ & $\begin{array}{l}\text { Institutionalization cantonal development } \\
\text { appears to solve problems of the media. }\end{array}$ \\
\hline $\begin{array}{l}\text { Plan of territorial } \\
\text { tourist organization-1977 }\end{array}$ & $\begin{array}{l}\text { Instrument of management, distribution, circulation and } \\
\text { standardization of procedures related only to tourism. }\end{array}$ \\
\hline $\begin{array}{l}\text { Socioeconomic } \\
\text { diagnosis-1979 }\end{array}$ & Statistical study to determine the potential of development \\
\hline $\begin{array}{l}\text { Local development } \\
\text { plan-1995 }\end{array}$ & Strategic tool to boost tourism and territorial organization \\
\hline $\begin{array}{l}\text { Update of the local } \\
\text { development plan of } 1995-2002\end{array}$ & $\begin{array}{l}\text { Document for the Territorial, Economic, } \\
\text { Socio-cultural, institutional-Municipal organization }\end{array}$ \\
\hline $\begin{array}{l}\text { Plan of territorial } \\
\text { organization } 2010\end{array}$ & $\begin{array}{l}\text { Study to boost the Territorial, Socio-cultural, } \\
\text { institutional-Municipal organization }\end{array}$ \\
\hline
\end{tabular}

Prepared by: Authors.

Table 2. Results.

\begin{tabular}{|c|c|c|c|c|c|c|c|c|c|c|}
\hline \multicolumn{11}{|c|}{$\begin{array}{l}\text { Subject: Evaluation of the stages of the management } \\
\text { for the development of Baños de Agua Santa }\end{array}$} \\
\hline $\mathbf{N}^{\bullet}$ & Items & & Meaning of colors & 1 & 2 & 3 & 4 & 5 & 6 & 7 \\
\hline 1 & Baseline study & G & Conflict solved & $\mathrm{R}$ & $\mathrm{R}$ & $\mathrm{R}$ & $\mathrm{R}$ & $\mathrm{R}$ & $\mathrm{R}$ & $\mathrm{R}$ \\
\hline 2 & Citizen participation & g & Conflict almost solved & $\mathbf{R}$ & $\mathbf{R}$ & $\mathbf{R}$ & $\mathbf{R}$ & $\mathbf{R}$ & $\mathrm{Y}$ & $\mathrm{Y}$ \\
\hline 3 & Strategic planning & $\mathrm{Y}$ & Neutral & $\mathbf{r}$ & $\mathbf{r}$ & $\mathbf{r}$ & $\mathbf{r}$ & $\mathbf{r}$ & $\mathbf{r}$ & $\mathbf{r}$ \\
\hline 4 & Participatory budget & $\mathrm{r}$ & Very serious conflict & $\mathbf{r}$ & $\mathbf{r}$ & $\mathbf{r}$ & $\mathbf{r}$ & $\mathbf{r}$ & $\mathbf{r}$ & $\mathbf{r}$ \\
\hline 5 & $\begin{array}{l}\text { Administrative territorial } \\
\text { and economic integration }\end{array}$ & $\mathrm{R}$ & Serious conflict & $\mathbf{r}$ & $\mathbf{r}$ & $\mathbf{r}$ & $\mathbf{r}$ & $\mathbf{r}$ & $\mathbf{r}$ & $\mathrm{Y}$ \\
\hline 6 & Enhancer of development & $\mathrm{W}$ & Blank vote & $\mathbf{Y}$ & $\mathrm{Y}$ & $\mathbf{Y}$ & $\mathrm{Y}$ & $\mathrm{Y}$ & $\mathrm{Y}$ & $\mathbf{Y}$ \\
\hline 7 & Management model & B & Not participate & B & B & B & B & B & B & B \\
\hline
\end{tabular}

Prepared by: Authors Source: Matrix of parameters of development of Baños. 


\section{Interpretation:}

- The information-collecting process presents important issues, because they confuse indexes with indicators and the variables that will be used as the basis for the analysis and decision-making, so they are very limited in all processes of management for development. It is recommended to use physical, biological, human development, demographic, institutional, legal, economic, and socio-economic indicators.

- The opinion of the population in the structuring of the development has never been considered nor required. After the adoption of the Constitution of Ecuador (2008), the participation in the construction of competence development and implementation of well-being is mandatory, but up until now, decisions and policy strategies affect more on the opinion of the local population and on the guidelines for sustainable development.

- Conditions of competition with multiple and global objectives to promote the territorial competitiveness, and employment for social cohesion have not been created. Also, environmental balance of the environment for the conservation of the territorial-production system has not been promoted, either. Therefore, systematization, organization and dynamics of the processes of strategic planning and management for territorial development are important issues.

- Since 2008, the new Constitution of the Republic of Ecuador promotes the creation of participatory budget aiming to promote equity in the distribution of wealth, but it has been ignored up to the present. Individual political interest has been put in the first place to this legal regulation. Citizenship participation has been put aside in structuring budgets.

- From the perspective of the territory, sustainable development has not been generated. This is a problem due to the absence of dynamic and comprehensive analysis of the economic, socio-cultural, environmental and political-institutional dimensions, which has not helped to promote the welfare of the urban and rural society. This is evident in each territorial development proposal that has not generated the territorial administrative and economic integration as a process of decentralization payer whose development policies are only oriented to the urban sector.

- Various proposals for territory development have not been able to consolidate the design of a policy to promote the economic development that create conditions (business climate) that facilitates the development of investment initiatives for the increase in production and employment in the framework of endogenous development which is oriented to the equitable and inclusive economic development. This would take advantage of the conditions of productive chains and the creation of sustainable employment, overcoming the gaps in the market that are derived from the promotion of production, taking as a basis the local human resources.

- The evaluation of the proposals of development has helped to determine that it has been impossible to diversify the economic and social activities in the territory of the local level on the basis of the mobilization and coordination 
of resources-both material and immaterial, since there has not been an optimal implementation of the administrative process. It was evident that there is a management model for sustainable development which will not be able to explain, describe or predict some aspect of reality for the decision-making process. All proposals have been characterized to be ideas, diagnostics, and inconsistent development plans because they do not have a line of long-term integration development.

This interpretation shows that the use of the territory for the development and economic growth in a disorganized way has generated social, territorial, legal, and economic conflicts among locals and the floating population, as a result of the lack of a process through which all the inhabitants aim their actions to achieve common development goals.

In this sense, it is imperative to evaluate the external factors (EFE), internal factors (EFI), from the SWOT matrix in order to promote strategic evaluation and position of action (EEAP) on the basis of descriptive statistics to know where to route the development strategies and policies (Figure 2).

The results from the matrix of strategic diagnostics help delineate the position and type of strategy to take (Figure 3 ).

Graphically it is demonstrated the type of strategic policy that has to be taken in Baños when promoting a policy of development, on the basis of their external and internal factors.

\begin{tabular}{|c|c|c|c|c|c|c|c|}
\hline \multicolumn{4}{|c|}{ External Factors Evaluation (EFE) } & \multicolumn{4}{|c|}{ Evaluation of Internal Factors (EFI) } \\
\hline OPPORTUNITIES & PERO & GRADE & WEIGHTING & STRENGTHS & PERO & GRADE & WEIGHTING \\
\hline $\begin{array}{l}\text { Baños well-known tourist } \\
\text { destination }\end{array}$ & 0.2 & 2 & 0.4 & Variety of Natural Resources & 0.13 & 4 & 0.52 \\
\hline A milllon of annual visitors & 0.16 & 4 & 0.64 & Geographic Location & 0.1 & 4 & 0.4 \\
\hline Tour Plan 2020 & 0.1 & 2 & 0.2 & Pleasant subtropical climate & 0.1 & 4 & 0.4 \\
\hline \begin{tabular}{|l}
$\begin{array}{l}\text { National Calendar of tourist } \\
\text { holidays }\end{array}$ \\
\end{tabular} & 0.05 & 2 & 0.1 & Enterprising people & 0.07 & 3 & 0.21 \\
\hline $\begin{array}{l}\text { Funding from international } \\
\text { agencies }\end{array}$ & 0.1 & 2 & 0.2 & Financial liquidity & 0.09 & 4 & 0.36 \\
\hline THREATS & & & & WEAKNESSES & & & \\
\hline Increase in the Tourist demand & 0.2 & 1 & 0.2 & $\begin{array}{l}\text { Territorial expansion without } \\
\text { planning }\end{array}$ & 0.2 & 2 & 0.4 \\
\hline $\begin{array}{l}\text { Competetion against other } \\
\text { tourist destinations }\end{array}$ & 0.11 & 4 & 0.44 & $\begin{array}{l}\text { Absence of environmental } \\
\text { management }\end{array}$ & 0.12 & 4 & 0.48 \\
\hline \begin{tabular}{|l|} 
Inappropriate advice on \\
tourism development
\end{tabular} & 0.04 & 2 & 0.08 & Poor signaling and road system & 0.09 & 4 & 0.36 \\
\hline $\begin{array}{l}\text { Process of eruption of the } \\
\text { Tungurahua volcano }\end{array}$ & 0.02 & 2 & 0.04 & No strategies of star product & 0.05 & 4 & 0.2 \\
\hline $\begin{array}{l}\text { Traffic jams through limited } \\
\text { road access }\end{array}$ & 0.02 & 2 & 0.04 & $\begin{array}{l}\text { Linking strategies of foreign labor } \\
\text { and unskilled labor }\end{array}$ & 0.05 & 4 & 0.2 \\
\hline Total & 1 & & 2.34 & & 1 & & 3.53 \\
\hline \multicolumn{8}{|c|}{ STRATEGIC POSITIONING AND EVALUATIONPEEEA } \\
\hline FACTORS & \multicolumn{2}{|c|}{ INDICATORS } & & AVERAGE & \multicolumn{2}{|c|}{ VECTORS } & RESULTS \\
\hline \multirow{2}{*}{ INTERNAL } & \multicolumn{2}{|c|}{ Financial strength } & & 3.8 & \multirow{2}{*}{\multicolumn{2}{|c|}{ AXIS X }} & \multirow{2}{*}{1} \\
\hline & Compet & advantage & & 2.8 & & & \\
\hline \multirow{2}{*}{ EXTERNAL } & \multicolumn{2}{|c|}{ Industrial strength } & & 3.2 & \multirow{2}{*}{\multicolumn{2}{|c|}{ AXIS Y }} & \multirow{2}{*}{0.7} \\
\hline & Environr & tal stability & & 2.5 & & & \\
\hline
\end{tabular}

Figure 2. Matrix of strategic diagnosis (EFE, EFI, SWOT, EEAP) decision. Source: Compiled by the authors. 


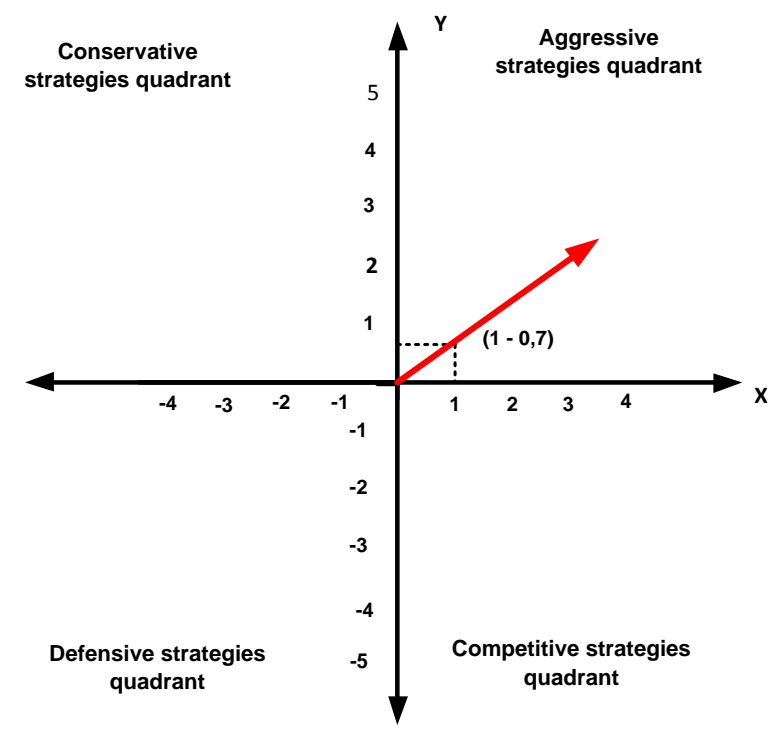

Figure 3. Strategic positioning quadrant Source: compiled by the authors.

\section{Discussion}

Baños de Agua Santa by its strategic geographic location has as its main strength natural resources weighted with 0.52 . However, its greatest weakness is the decline of the natural habitat by the misuse of resources and the absence of environmental management for sustainable development whose evaluation is 0.48 points. The results obtained from the matrix of factors internal EFI has as a general estimation 3.53. It means that there are strong internal features highlighting the strengths. From the external factors with 0.64 points determined as an opportunity the influx average of one million visitors a year; the emergence of other friendly new destinations similar to Ecuadorian's environment is an emerging threat punctuated with 0.44. Evaluations made on the basis of the matrix of external factors EFE have a total weight of 2.34 .

EFE and EFI matrixes are derived from the SWOT matrix, whose weights show that they do not respond correctly to the threats and opportunities that occur despite the existence of a high evaluation of the strengths. Concomitant indicator with the result of the matrix EEAP. This matrix determines that the strategies to be used for the sustainability of the tourist destination have to be aggressive, i.e. they must have well-defined competitive and comparative advantages that support the financial stability, determining the emergence of new competition as a critical factor.

\section{Conclusions}

For the creation of strategies for the development of Baños de Agua Santa, it is necessary the social understanding conceives the sustainability in the first instance as the relationship between man and nature in order to correct deficiencies in the use of natural resources and avoid new problems as a result of the shortcomings of a perspective of a scarce capitalist social system of sustainable development. 
The results obtained promote that for the structuring of aggressive strategies, the mobilization of a system of scientific concepts and theories to support the analysis and interpretations made is required. It can be emphasized that the strategies to be applied are characterized by merging the new proposals for management based on concepts such as: quality circles, cluster, productive chains, value chains, excellence, CRM, Total Quality Management, Reengineering, and Empowerment. All of them must coexist in an environment of social responsibility and participation.

While sustainability or sustainable development has emerged as an alternative for the development, the conception is concluded that based on the implementation of a policy genuinely participatory, each sector, group and individual in society can assume a particular responsibility and act correctly like stakeholders, who will maintain the productive and social processes during generational lapses and social importance. Equal or more resources and results will be obtained from these processes in order to reach a situation of potential development of society, in terms of substantive improvement of the levels and quality of life within a constitutional framework established and achievable.

\section{References}

[1] Rodríguez, C. (2007) Gestión local, ordenamiento territorial y prevención de riesgo. Módulo 13 Edición XI del Curso de Experto/a y en Dirección y Gestión Pública Local. Fundación DEMUCA/AECI/CMCI/UIM, La Antigua Guatemala, Guatemala, 49 p.

[2] Quevedo, J. (2013) Modelo de desarrollo territorial futuro. Producto borrador de la Unidad de Políticas Ambientales y de Sostenibilidad de la Dirección de Estudios Estratégicos de la Subsecretaría de Políticas Públicas de SEGEPLAN.

[3] Estrada Monterroso, J.C. (2006) Modelo de gestión territorial.

[4] Alfonso, A. (2009) Gestion territorial-comité bliviano UICN.

[5] Calvo Drago, J.D. (2006) El modelo de gestión territorial. En el XI Congreso Internacional del CLAD sobre la Reforma del Estado y de la Administración Pública, Ciudad de Guatemala, 7 - 10 Nov. 2006, 56-57.

[6] Rosa, H., Gómez, I. y Kandel, S. (2003) Gestión Territorial Rural. En Programa Salvadoreño de Investigación sobre Desarrollo y Medio Ambiente, PRISMA, 2003.

[7] Massiris Cabeza, Á. (2006) Ordenamiento territorial. Editorial: Universidad Pedagógica y Tecnológica de Colombia, UPTC.

[8] Rodríguez Valbuena1, D. (2010) Territorio y territorialidad Nueva categoría de análisis y desarrollo didáctico de la Geografía. Universidad Pedagógica y Tecnológica de Colombia, Tunja, Vol. 10 No. 3.

[9] Delgadillo Macías, J. (2009) La gestión territorial como instrumento para el desarrollo rural. Universidad nacional autónoma de México estudios agrarios.

[10] Constitución de la República del Ecuador (2008).

[11] Plan Nacional del Buen Vivir 2013-2017.

[12] Plan Estratégico de Desarrollo de Turismo Sostenible de Ecuador al (2007) Plandetur 2020. 128-167.

http://www.turismo.gob.ec/wp-content/uploads/downloads/2013/02/PLANDETUR-2 020.pdf

[13] Mesino Rivero, L. (2010) Las políticas fiscales y su impacto en el bienestar social de la 
población venezolana. Un análisis desde el paradigma crítico. Período: 1988-2006. Edición electrónica gratuita. http://www.eumed.net/tesis/2010/lmr/

[14] Aguilar, S., Font, N. and Subirats, J. (2000) Política ambiental de España. Subsidiariedad y desarrollo sostenible, 90, 306-313. http://www.redalyc.org/articulo.oa?id=99717877015

[15] Adams, W.M. (2006) The Future of Sustainability: Re-Thinking Environment and Development in the Twenty-First Century. 1-19.

http://cmsdata.iucn.org/downloads/iucn_future_of_sustanability.pdf

[16] Diez, T. and José, L. (2011) Posibilidades y retos del desarrollo sostenible en la región Tacna. 38-51. http://www.eumed.net/tesis-doctorales/2011/ljtd/index.htm

[17] Serna Gómez, H. (1999) Planeación y gestión estratégica. Fondo editorial LEGIS, Bogotá, 5-255.

[18] Instituto Ecuatoriano de Estadísticas y Censos INEC (2015). http://redatam.inec.gob.ec

[19] (2011) Diccionario de economía y negocios. Editorial Espasa Calpe, Barcelona, 700 p.

[20] Bernis, F. and María, J. (2008) Un modelo racional de organización territorial. Aplicación a Cataluña. 69-105. http://www.eumed.net/libros-gratis/2008b/410/\#indice

[21] Autor corporativo Gestión territorial (2011). 5-7. http://cmsdata.iucn.org/downloads/_cartilla_gestion_territorial.pdf

[22] Monteagudo, M., Yanisley, Vadez, G., Leidy, B., Martinez, M. and Cristóbal, C. (2009) Procedimiento para el diagnóstico estratégico de una empresa turística. Revista Retos Turísticos, 8, 8-12.

[23] Oscar Efrén Reyes-Baños de los Orígenes del Cabildo (2001) Factores de Formación y Estabilización de Pueblo Nuevo-Pág. 71-73.

[24] León María Vieira (1991) Baños Lugares Turísticos Agoyán SINTESIS. La Junta Pro mejoras fue legalmente expedida médiate decreto nacional № 180 del 23 de junio, en el gobierno del Ing. Federico Páez.

[25] Plan de Ordenamiento territorial Turístico de Baños (1977) Volumen 1, 2, 3- Estudios y proyecciones técnicas.

[26] Ángel Sánchez-Daniel Guevara (1979) El cantón Baños y sus posibilidades de Desarrollo Económico.

[27] Informe Plan de Desarrollo (1995) Ilustre Municipalidad del Cantón Baños de Agua Santa.

[28] Informe Plan de Desarrollo (2002) Ilustre Municipalidad del Cantón Baños de Agua Santa.

[29] Plan de ordenamiento territorial (2010) Gobierno Autónomo descentralizado del Cantón Baños de Agua Santa. 
Submit or recommend next manuscript to SCIRP and we will provide best service for you:

Accepting pre-submission inquiries through Email, Facebook, LinkedIn, Twitter, etc. A wide selection of journals (inclusive of 9 subjects, more than 200 journals)

Providing 24-hour high-quality service

User-friendly online submission system

Fair and swift peer-review system

Efficient typesetting and proofreading procedure

Display of the result of downloads and visits, as well as the number of cited articles Maximum dissemination of your research work

Submit your manuscript at: http://papersubmission.scirp.org/

Or contact tel@scirp.org 